Original research / Orijinal araştırma

\title{
Heat Shock Protein 70 extraction from human tooth for ELISA
}

\author{
ELISA için insan dişinden ISı şok protein 70 ekstraksyonu
}

Yakup Gülnahar $^{1}$

Department of Oral and Maxillofacial Surgery, Faculty of Dentistry, Cumhuriyet University, TR-58140 Sivas

\begin{abstract}
Protein extraction from bone is extremely difficult task because the bone tissue is hard to dissolve. Special care must be taken during extraction to prevent protein degradation and/or unfolding. Boiling is a traditional method for extracting protein from bones, but heat denaturation during this process destroys tertiary structure of some proteins irreversibly. Dental sciences employ tooth based research and extraction of proteins or other macromolecules from tooth are required most of the time. A new method was developed in our laboratory to extract proteins from tooth. This method overcomes heat or chemical denaturation of proteins and requires couple days. Although the method extract relatively less protein, the total amount of protein is sufficient for ELISA and proteomics.
\end{abstract}

Keywords: Heat Shock Protein 70, tooth, ELISA

\section{Özet}

Kemikten protein ekstraksiyonu, kemik doku oldukça zor çözündüğü için, zor bir işlemdir. Ekstraksiyon sırasında protein yıkımını ve/veya doğal üç boyutlu yapısının bozulmasını önlemek için özel önlem alınmalıdır. Kaynatma işlemi kemiklerden protein ekstraksiyonu için geleneksel bir yöntemdir; fakat, bu işlem sırasında ısı kaynaklı denatürasyon bazı proteinlerin üçüncül yapılarını geri dönüşümsüz olarak bozmaktadır. Diş bilimlerinde diş ile ilgili çalışmalar, çoğu kez, dişten protein veya diğer moleküllerin ekstraksiyonunu gerektirir. Laboratuarımızda dişten protein ekstraksyonu için yeni bir metot geliştirildi. Bu metot ISı ve kimyasal denatürasyonun önüne geçmekte ve sadece

\footnotetext{
${ }^{1}$ Corresponding author:
}

Dt. Yakup Gulnahar, Ağız ve Diş, Çene Hastalıkları ve Cerrahisi Anabilim Dalı, Cumhuriyet Üniversitesi Diş Hekimliği Fakültesi, TR-58140 Sivas

E-mail: yakupgInhr@yahoo.com 
bir kaç günlük çalışma zamanı gerektirmektedir. Yeni metot ile göreceli olarak daha az protein ekstrakte edilse de, ELISA ve proteomik çalışmaları için yeterli total protein elde edilebilmektedir.

Anahtar Sözcükler: Isı şok protein 70, insan dişi, ELISA

\section{Introduction}

Traditional protein research necessitates bulk amount of proteins. Thanks to recombinant DNA technology milligrams of protein can be prepared. However, this brings about a lot of problems, such as protein aggregation or the protein sample prepared may not undergo necessary posttranslational modifications. Therefore the new technique presented in the enables scientist to work in in vivo conditions. Proteomics, ELISA and so forth needs micro or nanograms of protein.

Dental research based on tooth requires protein extraction and extracting protein form hard tissues is a difficult task. In a recent work, proteins extracted from a dog skull for LC-MS-MS studies prompted us to extract protein from a human tooth (1). Extracting protein from tooth will enable researchers to examine several different properties of proteins. Stress or other factors on tooth protein patterns may also be traced by investigating protein content.

One basic measure of stress factor is the determination of Heat shock protein (Hsp) family expression in tissues (2). Heat shock proteins are expressed both under normal and adverse conditions. Expression under normal conditions is called "cognate" and under stress conditions is called "inducible". Heat shock protein families are often distinguished by their molecular weight, i.e. Hsp70 has a molecular weight of ca. $70 \mathrm{kDa}$ $(3,4)$.

Hsp70 is located at the heart of the family. It consists of three domains, N-terminal domain, middle domain and C-terminal domain (5-9). N-terminal domain is an ATPase with a U-shaped structure where ATP penetrates inside the cavity. Energy released from this domain is transmitted to the middle, substrate binding domain. This domain also has a cavity and a lid covering the cavity, and thus forming a protected area. The area is formed by hydrophobic residues, helping unfolded substrate proteins to fold in an isolated environment. Energy released from the ATPase domain regulates opening and closing of the lid. The ADP-bound protein is more stable than its ATP-bound state. The cavity may hold up to seven residues and can process seven residues at a time. Cterminal part of the protein has a unique primary structure interacting with other proteins (7-11).

Hsp70 protein interacts with several different proteins. For example, nucleotide exchange proteins can interact with Hsp70 to remove ADP from it so that a new folding cycle can commence (9-12). This way Hsp70 along with coordinating proteins help the substrate protein solubility by preventing them from forming aggregates. Conformational problems may also lead to aggregation. For instance, prion forms of the 
substrate proteins cause conformational artifacts. Aggregate forms of prions can serve as infectious agents causing several severe neurodegenerative diseases, which are commonly named as transmissible spongiform encephalopathies (TSEs). TSEs include mad-cow disease, scrapie, Creutzfeldt-Jakob disease and Kuru (12-15). Hsp70 plays a key role in cytoprotection by solubilization of protein aggregates and by refolding peptides. Increase in the intracellular levels of Hsp70 was observed in diabetes, trauma, Alzheimer's, Parkinson's, Huntington's, and cardiovascular diseases (12-15).

Hsp70 has several isoforms in the cell. For example, yeast cytosol has four different Hsp70. The reasons for why Hsp70 exists as different isoforms or inducible forms, are not known. The redundant forms may interact with different proteins, such as Hsp40. It should be kept in mind that a cell needs functional proteins. Unfolded or partially folded proteins may not function properly. Thus the proteins of a cell must first be sorted. Sorted macromolecules may then either be directed to lysosomes or to Hsp70 for the proper folding (12-15).

A cell cytoplasm is a crowded environment and protein-protein interaction can sometimes be dangerous. Here the function of Hsp family prevents such interactions (15-17).

Hsp70 coordinates with Hsp40 and Hsp100 protein (18). Hsp40 has a unique shape to stretch substrate molecules and to submit them to Hsp70. Hsp70 can then process substrate proteins readily. Several different Hsp40 exists. Some of them also contain ATPase activity similar to those of Hsp70s. Hsp100 family also coordinates with Hsp70 and Hsp40 during disaggregation. Hsp100 breaks large aggregates into smaller parts. During this process the Hsp100 hexamer chops off the aggregates into smaller pieces or fibrils, known as the crowbar effect (15-17). Hsp100 is made up of two discs, each with a hexameric structure and behaving like a blade. After breaking the protein aggregates into smaller structures Hsp100 is released from the substrate. Hsp100 has a hole right in the middle and sends the substrate protein into this hole. This prevents substrate protein from interacting with other molecules. At the end of the hole, Hsp70 and Hsp40 wait for the substrate protein to fold (18-23).

\section{Materials and methods}

Five different teeth were soaked into liquid nitrogen immediately after their removal from mouth and stored at $-86 \circ \mathrm{O}$. Frozen teeth samples were minced by a grinder and powdered in a mill to increase the surface area. Solution A (100 mM Tris, 0.5 M EDTA, 2 $\mathrm{M} \mathrm{HCl}, \mathrm{pH}$ 7.4) was used to extract tooth proteins. Samples were pre-incubated in a solution including 0.5 M EDTA, 1.2 M HCl, pH 7.4, for overnight for the demineralization of the samples at $4 \stackrel{\circ}{\circ}$. The samples were then incubated in solution A for $48 \mathrm{~h}$ at $4 \stackrel{\circ}{ } \mathrm{C}$. The proteins were acetone precipitated and were then lyophilized, dissolved in a commercial kit solution. Same experiments repeated with exactly same solutions, except that this time $6 \mathrm{M} \mathrm{HCl}$ were used. 


\section{Results and discussion}

Isolated tooth proteins were identified by ELISA, using specific antibodies and the results indicated the existence of $\mathrm{Hsp70}$ in the extracted tooth proteins (manuscript in preparation). The results also indicated that the amounts of Hsp70 increased by stress factors. Therefore the present study clearly demonstrated that Hsp70 as well as all other Hsp proteins can be extracted from a tooth samples. The use of $3 \mathrm{M}$ urea did not denature the proteins but help them to dissolve.

\section{Conclusions}

This paper presented a novel technique for the extraction of total proteins of hard tooth samples. The method can be adjusted depending on the protein structure. If for example the proteins are denatured reversibly, then urea concentration can be increased up to $6 \mathrm{M}$ to shorten the extraction time. If the proteins are denatured irreversibly, then the urea concentration could be decreased to $2 \mathrm{M}$. Both urea concentrations could be tried if the denaturation behavior of the proteins is not known, and this might also provide some information on the biochemical nature of the proteins.

\section{Conflicts of interest}

The author stated no conflicts of interest.

\section{Acknowledgements}

This work was funded by Cumhuriyet University Graduate School for Yakup Gulnahar. Samples were collected from randomly selected patients at Faculty of Dentistry. Collecting teeth samples for this retrospective study was done between January 2009 and May 2009. The author would like to thank Dr. Yusuf Tutar for his invaluable guidance in the accomplishment of the work.

\section{References}

1. Jiang $X$, Ye M, Jiang X, Liu G, Feng S, Cui L, Zou H. Method development of efficient protein extraction in bone tissue for proteome analysis. J Proteome Res. 2007 Jun;6(6):2287-94. Epub 2007 May 8. 2007 Nov;6(11):4528.

2. Sens DA, McGuirt JP, Khan W, Howell RM, Todd JH. Expression of hsc 70, but not hsp 70, in human third molar dental pulp. Eur J Oral Sci. 1997 Jun;105(3):271-7.

3. Sharma D, Masison DC. Protein Pept Lett. 2009;16(6):571-81. Review. Hsp70 structure, function, regulation and influence on yeast prions. 
4. Tutar Y, Song Y, Masison DC. Genetics. 2006 Feb;172(2):851-61. Epub 2005 Nov 19. Primate chaperones Hsc70 (constitutive) and Hsp70 (induced) differ functionally in supporting growth and prion propagation in Saccharomyces cerevisiae.

5. Sharma D, Martineau CN, Le Dall MT, Reidy M, Masison DC, Kabani M. Function of SSA subfamily of Hsp70 within and across species varies widely in complementing Saccharomyces cerevisiae cell growth and prion propagation. PLoS One. 2009 Aug 14;4(8):e6644.

6. Song $Y$, Wu YX, Jung G, Tutar $Y$, Eisenberg E, Greene LE, Masison DC. Role for Hsp70 chaperone in Saccharomyces cerevisiae prion seed replication. Eukaryot Cell. 2005 Feb;4(2):289-97.

7. Tutar L, Tutar Y. Heat Shock Proteins; An Overview. Curr Pharm Biotechnol. 2010 Feb 16.

8. Bukau B., Deuerling E., Pfund C. and Craig E. A. Getting newly synthesized proteins into shape. Cell. 2000 101:119-122

9. Aufricht C. Heat shock protein 70: Molecular supertool. Pediatr Nephrol 2005; 20: 707-713.

10. Hartl F. U. and Hayer-Hartl M. Molecular chaperones in the cytosol: from nascent chain to folded protein. Science. 2002 295: 1852-1858.

11. Goloubinoff P., Mogk A., Peres Ben Zvi A., Tomoyasu T. and Bukau B. Sequential mechanism of solubilization and refolding of stable protein aggregates by a bichaperone network. Proc. Natl. Acad. Sci. USA 1999 96: 13732-13737

12. Mayer MP, Bukau B. Hsp70 chaperones: cellular functions and molecular mechanism. Cell Mol Life Sci 2005;62(6):670-684.

13. Tutar L, Tutar Y. Ydj1 but not Sis1 stabilizes Hsp70 protein under prolonged stress in vitro. Biopolymers. 2008 Mar;89(3):171-4.

14. Genevaux P, Georgopoulos C, Kelley WL. The Hsp70 chaperone machines of Escherichia coli: a paradigm for the repartition of chaperone functions. Mol Microbiol 2007;66(4):840-857.

15. Ben-Zvi A. P. and Goloubinoff P. Review: mechanisms of disaggregation and refolding of stable protein aggregates by molecular chaperones. J. Struct. Biol. 2001 135: 84-93 
16. Ben-Zvi A., De Los Rios P., Dietler G. and Goloubinoff P. Active solubilization and refolding of stable protein aggregates by cooperative unfolding action of individual Hsp70 chaperones. J. Biol. Chem. 2004 279: 37298-37303

17. Diamant S., Peres Ben-Zvi A., Bukau B. and Goloubinoff P. Size-dependent disaggregation of stable protein aggregates by the DnaK chaperone machinery. J. Biol. Chem. 2000275: 21107-21113

18. Glover J. R. and Lindquist S. Hsp104, Hsp70 and Hsp40: a novel chaperone system that rescues previously aggregated proteins. Cell 1998 94: 73-82

19. Liberek K, Lewandowska A, Zietkiewicz S. Chaperones in control of protein disaggregation. Embo J 2008;27(2):328-335.

20. Frydman J. Folding of newly translated proteins in vivo: the role of molecular chaperones. Annu Rev Biochem 2001;70:603-647.

21. Hohfeld J, Cyr DM, Patterson C. From the cradle to the grave: molecular chaperones that may choose between folding and degradation. EMBO Rep 2001;2(10):885-890.

22. Kramer G, et al. The ribosome as a platform for co-translational processing, folding and targeting of newly synthesized proteins. Nat Struct Mol Biol 2009;16(6):589-597.

23. Young JC, Barral JM, Ulrich Hartl F. More than folding: localized functions of cytosolic chaperones. Trends Biochem Sci 2003;28(10):541-547. 